\title{
HIGH PREVALENCE OF NUTRITION RISK AMONG COMMUNITY LIVING OLDER PEOPLE IN WOERDEN, THE NETHERLANDS
}

\author{
T.A. Haakma, C.A. Wham
}

\begin{abstract}
Background: Undernutrition is a common problem in Dutch older people and may cause increased length of hospitalisation, early institutionalization and decreased quality of life. Nutrition risk precedes undernutrition and can be identified by timely nutritional screening. Design: This cross-sectional study aimed to examine the prevalence of nutrition risk among older people living in the community of Woerden. Measurements: Nutrition risk was assessed using a validated questionnaire: Seniors in the Community: Risk Evaluation for Eating and Nutrition, version II ('SCREEN II'). Participants: The sample ( $\mathrm{n}=335$, mean age 80 , age range $75-85$ ) were $32 \%$ men, $40 \%$ received home care and $46 \%$ lived alone. Results: Nutrition risk was present in two thirds $(67 \%)$ of the respondents (38\% 'at high risk', 29\% 'at risk'). The most common SCREENII items that led to nutrition risk were a low intake of meat and alternatives (65\%), milk products (59\%), fruit and vegetables $(59 \%)$ and eating alone (56\%). Those who received home care were 1.8 times more likely to be at nutrition risk than people without home care $(p=0.03)$ and those living alone were 3.3 times more likely to be at nutrition risk than those living with others $(p<0.001)$. Conclusions: Intervention strategies are needed to encourage Dutch older people to take opportunities to eat meals with others and to improve their intake of major food group items. Training of home care staff to identify nutrition problems should be prioritised.
\end{abstract}

Key words: Nutrition Risk, The Netherlands, older people, SCREEN II, home care.

\section{Introduction}

Maintaining health and functionality in older people $(>65 y)$ is very important for the maintenance of independence (1). The Dutch government aims to keep older people healthy, to allow them to live independently as long as possible in the community with relatively little care (2). To achieve that objective, the government invests in home care staff. The Dutch population is aging, the number of older people will increase rapidly from 2013 (3). Those over 65 years are expected to increase from 2.7 million (16\% of the entire population) in 2012 to a maximum of 4.7 million in 2041 (estimated to be $26 \%$ of the entire population). In the Netherlands the cost of living in an institution is estimated to be 6.000 to 16.000 euro per person per year more than living at home (4). Among older people who are in transition to move into an institution in the Netherlands the most important reason relates to a decrease in mobility (5). A large increase in institutionalized living older people is

The Hague University of Applied Sciences, Johanna Westerdijkplein 75, 2521 EN The Hague, The Netherlands

Corresponding Author: T.A. Haakma, Student at The Hague University of Applied Sciences, Design and conduct of study, data analysis, writing of manuscript. Breeveld 10a, 3445 BA Woerden, The Netherlands, Telephone: (+31) 0613684251, Email: tinekehaakma@hotmail.nl projected for those aged over 80 years (6).

Nutrition is an important determinant of health and functionality in older people (7). Poor nutrition, which refers to an inadequate, unbalanced diet (8) leads to undernutrition (9), which is associated with an increased length of hospital stay, early institutionalization (10), decreased quality of life (11) and may contribute to the development of disease (12). Undernutrition is related to long-term mortality in community dwelling as well as institutionalized older populations $(13,14)$ and is likely to cause an indirect increase in healthcare costs $(10,15)$.

Early recognition of undernutrition is important as nutritional intervention can reduce complications and further impairment of nutritional status $(14,16)$. Undernutrition is preceded by a state of nutrition risk, which can be identified by nutrition risk screening (17). Among Dutch older people almost a third (29.5\%) is at risk of undernutrition in chronic care institutions (living, care and wellbeing institutions, mean age 83.6) and $22.7 \%$ are at risk of undernutrition in home care settings (mean age 79.0) (18). Using the SNAQ-criteria (Short Nutrition Assessment Questionnaire 65+), 9.2\% of Dutch older people receiving home care were identified to be at nutrition risk compared to $7.7 \%$ without home care (mean ages 81.6 and 77.3 years, respectively) (14). 
The current prevalence of nutrition risk amongst independently living older people in The Netherlands is unknown. The aim of this study was to assess the prevalence of nutrition risk of community dwelling older people, identify common risk factor items and compare nutrition risk status of those with and without home care.

\section{Methods}

\section{Participants}

A cross-sectional study was undertaken amongst older people from the community of Woerden. Woerden is considered to be a typical community in The Netherlands on the basis of population structures such as age, gender, income, and nationality. Inclusion criteria for recruitment were age 75-85 years (born between 1929 to1939) and Dutch nationality. The sample size was set for 334 older people within the age range of 75-85 years, applying $95 \%$ reliability and 5\% margin of error.

\section{Participant recruitment}

Participants responded to advertisements in two regional newspapers, through home care staff working in the community, by participant acquaintances and direct contact through arranged activities across the Woerden community for older people.

The Medical Ethics Review Committee (METC, UMC Utrecht) deemed the study to be of low risk and therefore an official approval of the study was not required under The Medical Research Involving Human Subjects Act (WMO) (reference number WAG/th / 14/020125).

\section{Data collection}

Data collection was undertaken by a postal survey in April/May 2014. Participants completed a questionnaire sent to their private home $(20.5 \%)$, in groups of people, facilitated by the activity arranging organisation 'Welzijn Woerden' $(44.4 \%)$, by face to face interviews with the researcher $(29.5 \%)$ or by email $(5.6 \%)$.

\section{The questionnaire}

The questionnaire consisted of 23 items, 6 items for personal characteristics and home care, 3 items for evaluation of their acquaintance with the study and 14 items for an assessment of nutrition risk. Nutrition risk was measured using a Dutch translation of the validated questionnaire 'Seniors in the Community: Risk Evaluation for Eating and Nutrition, version II' (SCREEN II) with questionnaire items about weight change, food intake and risk factors for food intake. For each item the scores ranged from zero to four and the maximum score was 64 . The total score was categorized as: 'not at risk' (score $\geq 54$ ), 'at risk' (score $=50-53$ ) or 'at high risk' (score $\leq 49$ ) (19). Participants 'at risk' or 'at high risk' were referred to a physician or dietitian.

\section{Statistical analysis}

Descriptive statistics were completed for demographic items, living situation and professional home care data. The univariate associations between nutrition risk category and the variables gender, living situation and professional home care were tested by Pearson chi-square tests and odds ratios. Multivariate binary regression analysis was used to show whether the associations were maintained when all variables were included (gender, living situation and home care). Pearson Chi-square test was used to determine differences in nutrition risk items for participants who received home care versus who did not. P value below 0.05 was considered as significant. Statistical analyses were performed with SPSS 22.0 for Mac.

\section{Results}

\section{Participant characteristics}

There were 335 participants included in the study, with a mean age of $79.9( \pm 2.96)$ years (Table 1$)$. There were more women $(68 \%)$ and fewer participants lived alone (46\%) compared to the population of 2573 older people aged 75 to 85 living in Woerden (Table 1). A total of $40 \%$ of the participants received professional home care, which was similar to the Woerden community.

Table 1

Participants characteristics

\begin{tabular}{|c|c|c|c|}
\hline & $\begin{array}{l}\text { Respondents } \\
\qquad(\mathrm{n}=335)\end{array}$ & $\begin{array}{l}\text { Woerden } \\
\left(n=2573^{a}\right)\end{array}$ & P-value \\
\hline \multicolumn{4}{|l|}{ Gender } \\
\hline Female & $67.8 \%$ & $57 \%$ & \\
\hline Male & $32.2 \%$ & $43 \%$ & \\
\hline Total gender & & & 0.026 \\
\hline \multicolumn{4}{|l|}{ Living situation } \\
\hline Lives alone & $46.3 \%$ & $56.8 \%$ & \\
\hline Lives with others & $53.7 \%$ & $43.2 \%$ & \\
\hline Total living situation & & & 0.026 \\
\hline \multicolumn{4}{|l|}{ Professional home care } \\
\hline Yes & $39.7 \%$ & $32.5 \% \mathrm{~b}$ & \\
\hline No & $60.3 \%$ & $67.5 \%$ & \\
\hline Total prof. home care & & & 0.137 \\
\hline \multicolumn{4}{|c|}{$\begin{array}{l}\text { a. On the 13th of May 2014, information about population obtained by contact } \\
\text { with Town Council and includes people living in institutions }(n=59) ; \text { b. Based } \\
\text { on the percentage of valid AWBZ indications in Woerden on the } 1 \text { st of January } \\
2013 \text { and number of people who receive refund for help with domestic chores on } \\
\text { the } 27 \text { th of May 2014. AWBZ indications are statements for the right to receive } \\
\text { chronic care (27). }\end{array}$} \\
\hline
\end{tabular}


Table 2

Nutritional risk groups according to SCREEN II by gender, living situation and professional home care

\begin{tabular}{|c|c|c|c|c|c|}
\hline & \multicolumn{5}{|c|}{ Nutritional risk status (number and percentage) } \\
\hline & At high risk & At risk & Not at risk & Total & P-value \\
\hline \multicolumn{6}{|l|}{ Gender } \\
\hline Female & $91(42.7)$ & $59(27.7)$ & $63(29.6)$ & $213(100)$ & 0.026 \\
\hline Male & $29(27.6)$ & $33(31.4)$ & $43(41.0)$ & $105(100)$ & \\
\hline \multicolumn{6}{|l|}{ Living situation } \\
\hline Lives alone & $83(56.1)$ & $37(25)$ & $28(18.9)$ & $148(100)$ & $<0.001$ \\
\hline Lives with others & $37(21.8)$ & $55(32.4)$ & $78(45.9)$ & $170(100)$ & \\
\hline \multicolumn{6}{|c|}{ Professional home care } \\
\hline Yes & $65(50.8)$ & $33(25.8)$ & $30(23.4)$ & $128(100)$ & $<0.001$ \\
\hline No & $55(28.9)$ & $59(31.1)$ & $76(40.0)$ & $190(100)$ & \\
\hline Total & $122(38.4)$ & $91(28.6)$ & $105(33.0)$ & $318(100)$ & \\
\hline
\end{tabular}

Table 3

The odds ratiosa for gender, living situation and home care for those 'Not at risk' versus combined risk group)

\begin{tabular}{|c|c|c|c|c|}
\hline Variable & Univariate model & P-value & Multivariate model & P-value \\
\hline Gender (Female) & $1.65(1.01-2.69)$ & 0.043 & $1.01(0.59-1.74)$ & 0.98 \\
\hline Living situation (Lives alone) & $3.63(2.18-6.05)$ & $<0.001$ & $3.31(1.90-5.74)$ & $<0.001$ \\
\hline
\end{tabular}

a. Within the brackets, the $95 \%$ confidence intervals are displayed.

Table 4

The odds ratios ${ }^{\mathrm{a}}$ for gender, living situation and home care for those 'At risk' versus 'At high risk'

\begin{tabular}{lllll}
\hline Variable & Univariate model & P-value & Multivariate model & P-value \\
\hline Gender (Women) & $1.76(0.97-3.19)$ & 0.063 & $1.08(0.55-2.13)$ & 0.82 \\
Living situation (Lives alone) & $3.34(1.89-5.89)$ & $<0.001$ & $2.96(1.59-5.51)$ & 0.001 \\
Home care (Yes) & $2.11(1.21-3.69)$ & 0.008 & $1.76(0.98-3.15)$ & 0.057 \\
\hline
\end{tabular}

a. Within the brackets, the $95 \%$ confidence intervals are displayed.

\section{Nutrition risk}

Nutrition risk status was assessed in 335 participants. For 17 respondents $(5.1 \%)$ a score could not be assigned due to missing data. Using the SCREEN II questionnaire $38.4 \%$ of the respondents were 'at high risk' (SCREEN II score $\leq 49$ ), 28.6\% were 'at risk' (SCREEN II score 50-53) and $33.0 \%$ were 'not at risk' (SCREEN II score $\geq 54$ ) (Table $2)$. Half $(50.8 \%)$ of the older people who received home care were 'at high risk' compared to $27.7 \%$ of people who did not receive home care. Participants more likely to be at high nutrition risk were of female gender $(p=0.026)$, living alone $(\mathrm{p}<0.001)$ and receiving professional home care $(\mathrm{p}<0.001)$. (Table 5).

Participants in the categories 'at risk' and 'at high risk' were combined for further analysis. Significant univariate associations were observed for living situation and home care (Table 3). People living alone were 3.31 times more likely to be at risk than people living together. People who received home care were 2.18 times more likely to be at risk than people who do not receive home care. In the multivariate model (Table 4) the association between living alone and high nutrition risk persisted (controlled for gender and home care). The univariate associations between the variables gender and home care and nutritional risk were not maintained in the multivariate model.

Figure 1 shows the frequency of SCREENII nutrition risk items for those at risk. The six main nutrition risk items were low meat and alternatives intake (65.1\%), low milk product intake $(59.4 \%)$, low fruit and vegetable intake $(58.5 \%)$, eating alone $(55.7 \%)$, perception of own weight and difficulty cooking (both $42.5 \%$ ). 
Figure 1

Nutrition risk items for participants at nutrition risk

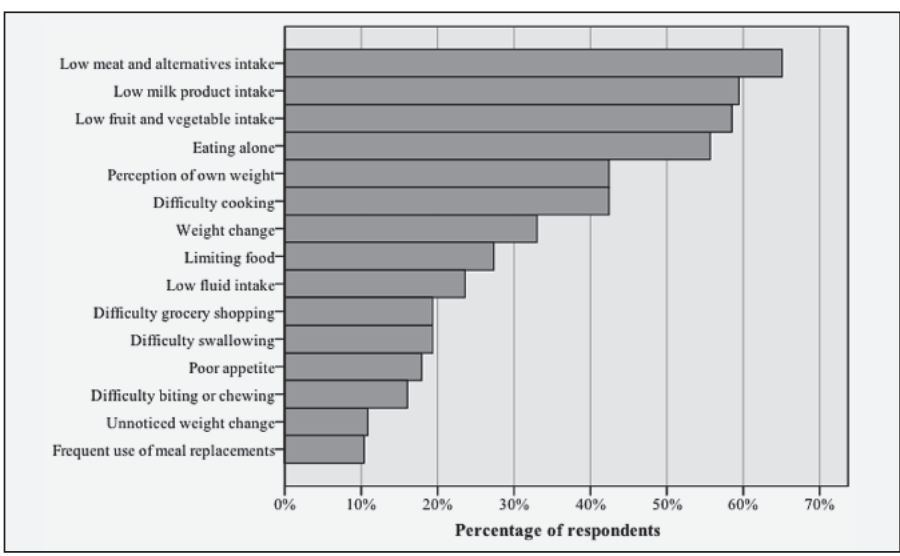

Table 5 shows nutrition risk items for people who do and don't receive home care. Those who receive home care are significantly more often at risk for eating alone, weight change, difficulty with grocery shopping, poor appetite, frequent use of meal replacements and unnoticed weight change.

\section{Table 5}

Nutrition risk items ${ }^{a}$ for respondents in the combined risk group who do and don't receive professional home care

\begin{tabular}{lccc}
\hline & $\begin{array}{c}\text { Without } \\
\text { home care }\end{array}$ & $\begin{array}{c}\text { With } \\
\text { homecare }\end{array}$ & $\begin{array}{c}\text { P- } \\
\text { value }\end{array}$ \\
\hline Low meat and meat alternatives & $34.0 \%$ & $31.1 \%$ & 0.5 \\
Low milk product intake & $34.9 \%$ & $24.5 \%$ & 0.08 \\
Eating alone & $25.0 \%$ & $30.7 \%$ & 0.004 \\
Low fruit and vegetables & $28.7 \%$ & $29.7 \%$ & 0.12 \\
Difficulty cooking & $21.2 \%$ & $21.2 \%$ & 0.34 \\
Perception of own weight & $21.7 \%$ & $20.8 \%$ & 0.54 \\
Weight change & $13.7 \%$ & $19.3 \%$ & 0.01 \\
Limiting food & $17.4 \%$ & $9.9 \%$ & 0.07 \\
Low fluid intake & $13.7 \%$ & $9.9 \%$ & 0.5 \\
Difficulty swallowing & $9.4 \%$ & $9.9 \%$ & 0.48 \\
Difficulty grocery shopping & $6.1 \%$ & $13.2 \%$ & 0.002 \\
Poor appetite & $7.1 \%$ & $10.8 \%$ & 0.05 \\
Difficulty biting or chewing & $7.5 \%$ & $8.5 \%$ & 0.39 \\
Frequent use of meal replacements & $2.8 \%$ & $7.5 \%$ & 0.008 \\
Unnoticed weight change & $2.8 \%$ & $8.0 \%$ & 0.005 \\
\hline a. SCREEN II items with scores less than or equal to two out of a maximum of four \\
potentially lead to nutrition risk (19) & & &
\end{tabular}

\section{Discussion}

This is the first Dutch study to identify the prevalence of nutrition risk among older people in the community using SCREEN II. Amongst people in Woerden over a third $(38.4 \%)$ were at high nutrition risk. Previously, Schilp et al. (2012) identified $7.7 \%$ of older Dutch community dwelling people were at nutrition risk using SNAQ65+-criteria. The discrepancy in nutrition risk prevalence may be due to differences in measures employed by the screening tools. The SNAQ65+ was validated by $6 / 15$ year-mortality risk (20) and the SCREEN II is validated against the criterion of a dietitians clinical judgement of risk (Keller et al. 2005). The AUC ('area under the curve') of the SNAQ65+ was overall poor $(55 \%)$ because people die of various other reasons than undernutrition (20). The AUC for SCREEN II was $82 \%$ and has been shown to have high inter-rater and test-retest reliability as well as excellent sensitivity and specificity in detecting malnutrition (19). The SCREEN II tool has also been identified to be more suitable for use in community dwelling older people compared to the SNAQ in general (21).

Nutrition risk items such as low intakes of meat and alternatives), milk products fruit and vegetables and eating alone found in the present study, are commonly occurring risk factors $(17,22)$. Low intake of fruit and vegetables and milk products has previously been reported in the Dutch National Food Consumption Survey Older Adults 70+ 2010-2012. Also, the survey concluded that Dutch older people (mean age 77.5) consumed less meat compared to people in their fifties or sixties (23). Meat and milk products provide over half $(53 \%)$ of the dietary protein for Dutch older people. Dietary protein is important for preserving bone and muscle mass in older adults (24).

Half $(50.8 \%)$ of older people who received home care in Woerden, were at high nutrition risk. Similarly using the MNA (Mini Nutritional Assessment) other European studies, from Finland and Germany, reported half of older people receiving home care were at nutrition risk $(25,26)$. Home care is indicated for people who have a functional disability (27). People with functional disabilities have an increased risk of undernutrition and the dietary intake of energy protein and vegetables may be lower than those without impaired function (23). A low intake of major food group items in those with and without home care in this study suggests those living in the community need to be screened for nutrition risk and provided with appropriate nutrition support.

In this study people who lived alone and received home care were the most nutritionally vulnerable and are an easily identifiable group. Using SCREEN II, previous studies also indicate that living alone is associated with nutrition risk among older people in Canada (28), Sweden (29) and New Zealand (17, 30). Older people living alone usually eat less than those who have the opportunity to share their meals (31).

The cross sectional design of this study does not allow us to comment on causality in factors related to nutrition risk and the findings should be interpreted cautiously. The participants involved in this study were representative of the population in Woerden on the basis of age, gender and living situation. Therefore, the findings are indicative of the nutritional risk 
status among older people in communities within The Netherlands. The validity of the SCREENII tool might be questionable from translation to Dutch. Although the tool was checked for comprehension, it is recommended that the SCREENII tool is validated for Dutch older people. As the SCREENII tool is suitable for self-administration and identifies nutrition risk factors screening for nutrition risk in community living older people could be cost-effective. The Dutch government has invested in a in a four-year program called 'Visible link', for employment of home care staff in order to keep older people living at home $(32,33)$. If the prevalence of nutrition risk remains unchanged, the absolute numbers of undernutrition in Dutch older people who receive home care will increase. The development of an intervention to prevent nutrition risk through home care staff could be effective to diminish nutrition risk. Another possibility is implementation of a digital version of SCREEN II, an intervention already active in Canada, known as Nutri-eScreen(C) (34). This e-version of the nutrition questionnaire provides feedback on which risk factor items are in need for improvement and could be very useful for older people and their carers for early identification of nutrition risk.

This study concludes that there are relatively high levels of nutrition risk among older community dwelling Dutch people aged 75 to 85 years living in Woerden. A low intake of essential food groups have been identified as important risk factors items. In order to maintain the independence of the older population it is recommended that older people are screened regularly for nutrition risk and, where necessary, effective nutrition intervention is provided.

Acknowledgements and funding: Not applicable. No funding, no acknowledgements.

Conflict of interest: The authors declare no financial conflicts of interest.

\section{References}

1. Beswick AD, Rees K, Dieppe P, Ayis S, Gooberman-Hill R, Horwood J, et al. Complex interventions to improve physical function and maintain independent living in elderly people: a systematic review and meta-analysis. The Lancet. 2008;371(9614):725-35.

2. Government of The Netherlands. Ouderen langer thuis wonen (Older people living independently) The Hague2015 [cited 201419 March]. Available from: http: / / www.rijksoverheid.nl/onderwerpen/ouderenzorg/ouderen-langerzelfstandig-wonen.

3. Giesbers H, Verweij A, Beer Jd. Vergrijzing: Wat zijn de belangrijkste verwachtingen voor de toekomst? (Aging: What are the most important expectations for the future?). Bilthoven: RIVM (National Institute for Public Health and the Environment), 2013.

4. Kok L, Stevens J, Brouwer N, van Gameren E, Sadiraj K, Woittiez I. Kosten en baten van extramuralisering (Costs and benefits of extramuralization). The Hague: 2004 90-377-0187-6.

5. Brands M, Zijderveld C. Ouderen op de grens van zelfstandig wonen naar verblijf (Older people in transition of independent living to living in an institution). Utrecht/ Woerden: NPCF/ ANBO, 2012.

6. CBS Statline. Personen in huishoudens naar leeftijd en geslacht, 1 januari (Persons in households by age and gender, January 1st) The Hague2013 [cited 201415 March]. Available from: http://statline.cbs.nl/StatWeb/publication/ ?DM=SLNL\&PA=37620\&D1=0,3-4,11\&D2=0\&D3=110-116\&D4=15,1\&HDR=T, $\mathrm{G} 3 \& \mathrm{STB}=\mathrm{G} 1, \mathrm{G} 2 \& \mathrm{~W}=\mathrm{T}$

7. Kuczmarski M, Weddle D. Position paper of the American Dietetic Association: nutrition across the spectrum of aging. Journal of the American
Dietetic Association. 2005;105(4):616-33.

8. World Health Organization. Nutrition 2015 [cited 20147 April]. Available from: http: / / www.who.int/topics/nutrition/en/.

9. Shetty P. Malnutrition and undernutrition. Medicine. 2003;31(4):18-22.

10. Correia MIT, Waitzberg DL. The impact of malnutrition on morbidity, mortality, length of hospital stay and costs evaluated through a multivariate model analysis. Clinical Nutrition. 2003;22(3):235-9.

11. Amarantos E, Martinez A, Dwyer J. Nutrition and Quality of Life in Older Adults. The Journals of Gerontology Series A: Biological Sciences and Medical Sciences. 2001;56(2):54-64.

12. Mowe M, Bøhmer T, Kindt E. Reduced nutritional status in an elderly population $(>70 \mathrm{y}$ ) is probable before disease and possibly contributes to the development of disease. The American Journal of Clinical Nutrition. 1994;59(2):317-24

13. Vischer UM, Frangos E, Graf C, Gold G, Weiss L, Herrmann FR, et al. The prognostic significance of malnutrition as assessed by the Mini Nutritional Assessment (MNA) in older hospitalized patients with a heavy disease burden. Clinical Nutrition. 2012;31(1):113-7.

14. Schilp J, Kruizenga HM, Wijnhoven HA, Leistra E, Evers AM, van Binsbergen $\mathrm{JJ}$, et al. High prevalence of undernutrition in Dutch community-dwelling older individuals. Nutrition. 2012;28(11):1151-6.

15. Meijers JM, Halfens RJ, Wilson L, Schols JM. Estimating the costs associated with malnutrition in Dutch nursing homes. Clinical Nutrition. 2012;31(1):65-8.

16. Elia M, Zellipour L, Stratton R. To screen or not to screen for adult malnutrition? Clinical Nutrition. 2005;24(6):867-84.

17. McElnay C, Marshall B, O'Sullivan J, Jones L, Ashworth T, Hicks K, et al. Nutritional risk amongst community living Maori and non-Maori older people in Hawke's Bay. Journal of Primary Health Care. 2012;4(4):299-305.

18. RIVM. Zorgbalans (Dutch Health Care Performance) 2013 [cited 201413 March]. Available from: http://www.gezondheidszorgbalans.nl/kwaliteit/ effectiviteit-van-langdurige-zorg/ondervoeding/.

19. Keller H, Goy R, Kane S. Validity and reliability of SCREEN II (Seniors in the community: risk evaluation for eating and nutrition, Version II). European Journal of Clinical Nutrition. 2005;59(10):1149-57.

20. Wijnhoven HA, Schilp J, de Vet HC, Kruizenga HM, Deeg DJ, Ferrucci L, et al. Development and validation of criteria for determining undernutrition in community-dwelling older men and women: The Short Nutritional Assessment Questionnaire 65+. Clinical Nutrition. 2012;31(3):351-8.

21. Phillips MB, Foley AL, Barnard R, Isenring EA, Miller MD. Nutritional screening in community-dwelling older adults: a systematic literature review. Asia Pacific Journal of Clinical Nutrition. 2010;19(3):440.

22. Keller HH, Hedley MR. Nutritional risk needs assessment of communityliving seniors: prevalence of nutrition problems and priorities for action. Journal of community health. 2002;27(2):121-32.

23. Ocke MC, Buurma-Rethans E, De Boer E, Wilson-van den Hooven C, EtemadGhameslou Z, Drijvers J, et al. Diet of community-dwelling older adults: Dutch National Food Consumption Survey Older adults 2010-2012. RIVM (National Institute for Public Health and the Environment), 2013050413001.

24. Genaro PDS, Martini LA. Effect of protein intake on bone and muscle mass in the elderly. Nutrition reviews. 2010;68(10):616-23.

25. Soini H, Routasalo P, Lagström H. Characteristics of the Mini-Nutritional Assessment in elderly home-care patients. European Journal of Clinical Nutrition. 2004;58(1):64-70.

26. Kiesswetter E, Pohlhausen S, Uhlig K, Diekmann R, Lesser S, Heseker H, et al. Malnutrition is related to functional impairment in older adults receiving home care. The Journal of Nutrition, Health and Aging. 2013;17(4):345-50.

27. CIZ Care Needs Assesment Centre. CIZ Basisrapportage AWBZ - Gemeente Woerden (Care Assesment Center basic report of the Exceptional Medical Expenses Act - Community Woerden). Woerden: 2013.

28. Ramage-Morin PL, Garriguet D. Nutritional risk among older Canadians. Statistics Canada, 2013 Contract No.: 3.

29. Westergren A, Hagell P, Hammarlund CS. Malnutrition and risk of falling among elderly without home-help service-a cross sectional study. Journal of Nutrition, Health and Aging. 2014;18(10):905-11.

30. Wham CA, Teh R, Robinson M, Kerse N. What is associated with nutrition risk in very old age? Journal of Nutrition, Health and Aging. 2011;15(4):247-51.

31. Salvà A, Pera G. Screening for malnutrition in dwelling elderly. Public Health Nutrition. 2001;4(6a):1375-8.

32. Government of The Netherlands. Uitvoering Motie Hamer (Implementation motion 'Hamer'). In: Sport MoHWa, editor. The Hague2008.

33. ZonMw. Zichtbare schakel. De wijkverpleegkundige voor een gezonde buurt. (Visible link. The community nurse for a healthy neighbourhood) 2008 [cited 201419 March]. Available from: http://www.zonmw.nl/nl/programmas/ programma-detail / zichtbare-schakel-de-wijkverpleegkundige-voor-eengezonde-buurt/.

34. Dietitians of Canada. Eating habits survey 2015 [cited 20152 March]. Available from: http:/ / www.nutritionscreen.ca/escreen/. 